\title{
Entrepreneurial Training Needs of Illiterate Women in Cross River State, Nigeria
}

\author{
Emmanuel U. Ingwu ${ }^{1} \&$ Stella-Maris A. Okey ${ }^{1}$ \\ ${ }^{1}$ Faculty of Education, Cross River University of Technology, Calabar, Nigeria \\ Correspondence: Emmanuel U. Ingwu, Faculty of Education, Cross River University of Technology, Calabar, \\ Nigeria. Tel: 234-805-927-7202. E-mail: unimke50@yahoo.com
}

Received: August 6, 2013

Accepted: September 12, 2013 Online Published: October 31, 2013

doi:10.5539/ies.v6n11p171

URL: http://dx.doi.org/10.5539/ies.v6n11p171

\begin{abstract}
In order to improve on the curriculum and participation rate of adult learners in the current Adult Basic Education (ABE) program in Nigeria, this explorative study investigated the entrepreneurial (or vocational) training needs of illiterate women in Cross River State (CRS). Three research questions were posed to elicit from the participants their demographic characteristics, perception of the ABE program and perceived entrepreneurial training needs. The descriptive-survey design was adopted for the study. The focus group discussion along with probing interview sessions were held with a sample of 240 women learners drawn from the urban and rural ABE centers. Frequencies, percentages and bar charts were used to report the data. The study shows that majority of the women are young, single, unemployed and dropped out of school and perceived the current ABE as not meeting their needs. Majority of the subjects desire training in home management, clothing and textiles. Those in the rural areas prefer training in agricultural production. A few of those in the urban centers prefer training in computer/secretarial related skills. The major conclusion of the study is that the learners (women) should be involved in identifying their learning needs that would at the end of the program empower them to improve on their livelihoods.
\end{abstract}

Keywords: entrepreneurial, training needs, illiterate women, adult basic education

\section{Introduction}

In Nigeria, like in many other African economies women play significant roles in the socio-cultural and economic development of their societies. The burden placed on them in many cultures is quite enormous. The overwhelming majority of them provide labour that sustains life-growing food, cooking, raising children, caring for the elderly, maintaining a house, hauling water, etc (Onwubiko, 2012). Even in many married homes, housewives do not fare better as they bear the cost of children's education and health with little or no support from their husbands. In many other settings too women continue to play the role of bread-winners and decision makers in the event of the demise of the father or inadequate male presence. This absence which could be brought about by death sickness or other forms of physical and mental incapacitation have thrust women in the centre stage for the performance of functions far removed from their traditional responsibility of house-keeping (Onwubiko, 2012).

These family commitments have compelled almost every housewife or woman to engage in various forms of economic activities that can generate income to meet family welfare and enhanced standard of living. In Nigeria, they are found in the informal sector such as mining, petty trading, hawking of food and in various forms of food crop production, fishing, tailoring, and so forth.

Although women are engaged in numerous productive undertakings, the returns to their efforts is quite minimal. Majority of them especially those in the traditional sector are unable to meet their needs and fulfill other family responsibilities. According to Okeem (1998), these women work two-thirds of the world's working hours. Yet, why are they unable to generate enough income? The major characteristics of these women is that they are illiterate. It is therefore presume that they lack the requisite skills and knowledge that would have improved their productive capabilities. This has consigned these families to a perpetual cycle of poverty.

A growing body of literature suggests that the economic impact of these women would have been much greater if they were educated or literate (Schultz, 1989; 1993; Todaro \& Smith, 2003; \& Oxenham, 2004). The 
consensual opinion is that the enrolment of these women, for instance, in adult and non-formal education programs improves not only their productivity levels. It may also lead to lowering fertility, infant and maternal mortality, as well as in enhancing longer life expectancy and improve the quality of life of both the family and the community (Bellew \& King, 1993). Given the role of women in the community generally, women education thus appear to have a greater impact on the family welfare at home than that of men (Oxenham, Diallo, Katahoire, Petkova-Nwangi \& Sall, 2002).

Many countries like in Nigeria, have responded to this challenge by providing adult basic education pograms for women. The Universal Basic Education Act (2004) makes it mandatory that every girl child and women should have unfettered access to educational programs that will see them out of generational and situational poverty (Federal Republic of Nigeria, 2004). To ensure that ABE programs are effectively managed, the National Commission for Mass Education and the State Agencies for Adult and Non-formal Education are established to mobilize, monitor and encourage these women to participate in the literacy classes.

The National Blue Print on Adult and Non-formal Education spells out the basic education program to include basic literacy, post literacy, continuing and vocational education. It further identifies the following as the core subject areas for out-of-school adolescent girls and illiterate women:

- $\quad$ basic literacy and numeracy

- $\quad$ civic, moral and political education

- $\quad$ health and nutrition education

- $\quad$ post literacy

- vocational education

- $\quad$ life skills.

Moreover, the Blue Print also recommends some topics for classroom interaction especially; home management, food processing, preservation and storage, small scale industries/cooperatives, key household practices, relevant technology, e.g. craft, etc (Federal Republic of Nigeria, n.d.). This policy on ABE for women is quite comprehensive. But it seems it has not been matched with appropriate action as it would soon be shown.

Monitoring and evaluation reports have shown that more illiterate women than men are taking advantage of these basic education classes that have been established in various parts of the country (Federal Ministry of Education, 2007). This is encouraging. In Cross River State of Nigeria reports from the Agency for Adult and Non-formal Education indicate that 62.9 percent of women as against 37.1 (for men) out of the total of 17,268 adult learners have enrolled in the classes (Ingwu, Ifere \& Abanbeshe, 2012). However, only 2.9 percent of the total population of illiterate adults and youths $(579,024)$ in the State are participating in the ABE programs (Agency for Adult and Non-formal Education, Cross River State, 2011). This is a far cry from what the providers of the programs envisaged

According to Thompson (2002), a combination of social, economic, cultural and psychological factors account for the apparently low level of motivation which has negatively affected the declining rate of participation in the literacy programs. Secondly, and more importantly, evidence from Nigeria (as reported in the Education Sector Analysis Diagnosis) reveals that adult education priorities and curricula are defined from the top (that is, at the federal level), as in the provision of agricultural extension, literacy and fundamental education, family planning, health, school leaving certificate, etc (FME, 2007), and handed down to the local level. This is the major cause of the declining rate in the number of centres and adult learners.

\subsection{Statement of the Problem}

The current adult basic education program that is going on in Nigeria for adult learners does not put "bread on the table". For instance, in a nutrition course on balanced diet, women are taught to give their families balanced nutrition such as carbohydrates, protein, vitamins, etc. They may internalized the knowledge. But they have not been exposed to entrepreneurial or vocational skills that can assist them in generating income to provide and prepare balance meals for their families.

Similarly, teaching women citizenship skills in order to meet their civic responsibilities of paying for water, electricity, etc, as well as voting wisely in choosing credible leaders that can represent them, they need training in vocational or entrepreneurial skills that will propel them to play their civic roles responsibly and stand up for their rights. 
It should be understood that the purpose of $\mathrm{ABE}$ is not to help the adult learners acquire certificates or knowledge for its own sake, but to acquire knowledge and skills that will be useful in solving their daily problems, and or find solutions to problems they face daily.

It is for the above reasons that this exploratory study is being undertaken to highlight the entrepreneurial training needs/skills desire by women who have enrolled in ABE programs in the Cross River State of Nigeria.

\subsection{Purpose of the Study}

The general aim of this study was to identify the entrepreneurial training needs of girls and young women who are participating in the Adult Education Programmes in Calabar metropolis in CRS, Nigeria. Specifically, the purpose of the study was to:

- Identify the demographic characteristics of women who are currently enrolled in the area under study.

- Critically appraise the perceptions of women on the current curriculum of the adult education programme in the study area.

- Identify the entrepreneurial training needs of subjects in the study area.

\subsection{Significance of the Study}

This study is significant for the simple reason that identifying the curricula needs of women in the acquisition of entrepreneurship skill would help in instituting ABE programs that can assist them acquire skills necessary for useful living.

\section{Review of Literature}

\subsection{Conceptual Background}

The conceptual background or theory provides the frame on which research findings are analyzed, interpreted and predicted. For the purpose of the present study we adopt the theory of participatory integrated development (PID). Thompson (2002) describes PID as an approach that involves meeting the diverse, often complex, social, economic, and cultural needs of people at both the individual and community levels. Meeting these needs in an integrated and holistic manner recognizes their organic relationship. These needs cannot be met without involving the people in the determination of what their basic needs are and what actions can be taken to mitigate these needs.

Participatory integrated development is therefore derived from the participatory research process in which the recipients of knowledge determine for themselves what they want to learn. It is through this process, argues Lees (1975), can the majority acquire the necessary knowledge, understanding and skills to comprehend and improve on their situation. Akinpelu (2002) opines that participatory research is a situational and action-oriented inquiry process that is triggered off by the existential needs of the people and not by the intellectual concerns of those in authority.

Participatory integrated development is democratic in approach. Personal, social and economic development is not dependent on the knowledge and power of the professional elite. Rather, the development is based on the mass participation and which in turn is based on popular knowledge, the development is not only effective but is long-lasting (Akinpelu, 2002). Hence, effective participation in development entails involvement of the people in key processes of identification, planning and programming as well as the implementation of the project.

The implication of this theory is that in planning non-formal education for women, for instance, there is need to involve them in identifying what their felt needs are so that these can be incorporated into the training programs. The success and effectiveness of these programs lie in helping women acquire the desired skills and knowledge that can graduate them out of poverty.

A major constraint to many Adult basic education delivery is linked to the "old fashioned, top down and teacher-centered approaches" (Thompson, 2002) and "a one-shot for all size" (Jauglo, 2002), which has severally restricted women attendance in the nation-wide literacy programs. According to the authors, these programs do not address the needs of the adult learners since they were planned from above and handed down to the learners without taking into consideration the peculiarities of the learners and their environment. Thompson (2002) reviewed four literacy education projects that were established for women in Kenya and drew a conclusion that the projects did not help them to "put bread on the table". He therefore advocated a paradigm shift from the centralized national programs to instituting $\mathrm{ABE}$ that will empower women and graduate them out of poverty.

A study by the Asia Pacific Bureau of Adult Education (ASPBAE) indicates that the literacy programs put in place by member countries were not attracting women to enroll because the programs are not contextualized. In 
other words, the learning activities are confined to the classroom and not extended into the daily life of the women. The Association notes further that concentrating on the generalized national literacy program as has been the case without diversifying it to suit the local needs of the adult learners from participating and even those who have enrolled dropping out from the programme (ASPBAE, 2002). Hence, in the thinking of the ASPBAE, literacy for adult learners can best be learned through a highly contextualized and even individualized program in which literacy learners are engaged in doing their own daily life literacy activities "learning by doing" rather than "learning in preparation for doing".

Oxenham, et al (2002:25-26) reviewed research on ABE and livelihoods in the developing countries and the following submissions were made:

- Developing literacy skills among the poorest sections of the society and particularly women requires more than the establishing of classes and waiting for people to come. It requires an holistic approach to awareness raising and helping them manage other challenges in their lives.

- Integrating and or incorporating livelihood and vocational training skills such as tailoring for women and other income generating projects such as poultry and goat-keeping, etc with literacy training has the effect of raising learners motivation thereby ensuring their faithful participation and sustainability. The authors note specifically that most of the participants who had earlier dropped out were willing to return to literacy classes, if, for instance, entrepreneurial skills training were included.

- Adult and non-formal education and training programs that are based on the problems and needs of the target groups are more likely to attract adult learners to the literacy programs.

The reviewed literature stressed the need for the decentralization of planning and the development of curriculum from the federal to the local level. This will give the adult learners the chance to participate in deciding what they want to learn. We need to apply the participatory approach where learners can express their own learning needs. It is these needs that can be translated into ABE programs that will become effective.

\subsection{What is Entrepreneurship Education and Training?}

From the literature, there appears to be little controversy concerning the meaning of entrepreneurship education. Adidu and Olannye (2006) see entrepreneurship education as a specialized training given to people to acquire the skills, ideas and the managerial abilities and capabilities for self-employment rather than being employed for pay It is a deliberate attempt to provide trainees with relevant knowledge, appropriate skills, competence and right attitude to effectively run or manage a business outfit. According to Agetue and Nnamdi (2011), entrepreneurship education enables beneficiaries to be employed, self-reliant, economically empowered and employers of labour.

To Nwodoh (2011), entrepreneurship education and training attempts to prepare people to be responsible enterprising individuals who become entrepreneurs or entrepreneurial thinkers and who contributes to economic development and sustainable communities. He goes further to state the objectives of entrepreneurship education to include:

- Developing people with the ability to be self-employed instead of seeking for who to employ them.

- Combining other factors of production to create products and services.

- Taking the risk of losing or succeeding in an enterprise.

- Identifying new business opportunities.

- Being creative and innovative.

Thus, entrepreneurship education simply stated, is a strategy designed to give individuals the opportunity to develop the potentials, acquire knowledge, skills, attitude and values necessary to do something to help themselves. It prepares children and youths for future self-employment especially in this global era where both public and private sector jobs are becoming scarce for the unemployed adults, entrepreneurship education will assist in identifying entrepreneurship skills available and train them to utilize them immediately.

Udo-Aka (2000) suggests that entrepreneur training is the development of personal qualities that is quit different from entrepreneurship development which provides training in the process of business creation. He identifies three levels of entrepreneurship training and development that occurs along a line of continuum, as follows:

Level 1: Entrepreneurship training at this stage is focused on the rural youths, illiterate men and women in traditional village trades like agriculture, carpentry, blacksmithing, etc. Much of the training at this level is devoted to technical skills and a small percentage to basic management tools and techniques. 
Level II: The focus here is on the establishment of larger and medium enterprises. The target participants are those who have been successful in self-employment and are ready to move up in technology and expand their operations.

Level III: The training program at this level is targeted at the potentially large scale entrepreneurs, with demonstrated record of success in a managerial and technical field.

According to Udo-Aka (2000), this continuum-based model of entrepreneurship development eliminates the confusion in the content of training programs for the development of entrepreneurs, entrepreneurship and self-employed.

For the purpose of the present study, the emphasis is on level 1 of the continuum, which represents the first step in the training of illiterate women desirous of becoming self-employed.

Entrepreneurship education is therefore, a form of training that if applied properly can graduate people out of poverty. Its emphasis is on self-employment and wealth creation. It gives the people the chance to participate in personal, socio-cultural and economic development of their societies.

Entrepreneurship training for women, especially the impoverished, with little or no formal education will go a long way to assist them acquire the desired skills to improve themselves: women who form the greater majority of the workforce in the traditional sectors of our economy like agriculture, home crafts, mining, etc need to sharpen their skills through entrepreneurship training. The latter's intervention can help them identify the areas they may be potentially good so that they can exploit them to their advantage.

\subsection{Identifying and Developing Entrepreneurial Training Programs for Women}

Illiterate women who attend $\mathrm{ABE}$ classes come from different and diverse cultural backgrounds. Hence, individual learner's needs may be different, varied and complex. They may want to learn things that relate to their lives, needs and interests. Thus, they may come to literacy classes with the expectations that the classes will address their problems and life concerns. For instance, they may wonder whether the literacy class can help them learn better ways of baking, farming, sewing, etc. (UNESCO, n.d.). In order to assist these women live happy lives, UNESCO (n.d.) suggests that there is need to identify their learning needs and reorient the curriculum to meet their training needs. For instance, there is need to know their background, the condition of their lives, their current skills and knowledge and their future needs. If we know their training needs we can better provide learning experiences because training will be most effective when learners have opportunity to learn things that relate to their lives and needs. It is in this respect that an assessment of learners training needs will assist program providers to facilitate purposeful and useful learning. It also helps to adapt curriculum, select relevant learning materials and to plan appropriate learning activities (UNESCO, n.d.).

The benefits of identifying women's educational needs before program planning and implementation is demonstrated by Marstaller (2012). She reveals in her study that the University of Florida partnered with the University centre in Dschang, Cameroun where students were taught a short course on curriculum development. The aim of the course was to help them design and implement "women and agricultural household program". The first order of business in the course was assessing women's needs and the accompanying personnel needs. For instance, meeting women's health and welfare needs require educators in family health and welfare needs require educators in family health and hygiene. While the need for income generating resources like land and credit calls for coordinators for women's cooperatives. According to Marstaller (2012), identifying the personnel needs that correspond with women's needs is a productive first step towards educational progress. Applying this model effectively has helped solved educational problems of women in the culturally and geographical diverse regions of Cameroun. Adapting this approach is also a major means of empowering women to increase their productive capacity in their chosen livelihood and enhance their bargaining power within the household.

Other studies have focused on a list of entrepreneurial skills that appeal to women. For instance, Lowe (1975) observed some three and half decades ago that women who attend adult education classes do have interest in such culturally feminine subjects like cooking, dress making and house design. He also added that in the rural areas of developing economies, there is need to create self-employment opportunities for adult learners through appropriate vocational preparation. Young married women do eagerly seek information about home and family living, child-care and matters related to their husbands work. And those women evince strong interest in vocational courses because of the desire to secure a job.

Many other adult education experts have also given us insight into those skills women who participate in literacy programmes like to learn. Some desire training in agriculture where they can be exposed to new production and cultivation techniques, budgeting, accountability and marketing techniques, access to micro-credit facilities, 
management of the environment for better productivity and sustainability of crops (Van der Linder and Rungo, $2006 \&$ Suso, 2006). Many want to develop abilities to prepare adequate meals and matters relating to nutrition, family life, education and vocational skills. Many welcome courses in starting small businesses and farming, animal husbandry, book keeping and other income generating skills (Oxenham et al, 2002).

Uzoka (2010) writing from the Home Economics background itemizes a range of entrepreneurial skills that benefit women especially in generating income and improve family welfare. She further pleads that women-folks, widows and poor at the grassroots level should be exposed to these skills if government is desirous of tackling poverty. The skills are itemized thus:

i. Skills in Home Management: Soap making, laundry and dry-cleaning, housekeeping, baby sitting, interior decoration, consumer education skills.

ii. Skills in Clothing and Textiles: Tailoring/dress making, clothes repairing, dying, embroidery, crocheting, weaving, knitting and hair dressing.

iii. Skills in Food and Nutrition: Bread making, sausage rolls, cakes, chin-chin, akara, moi-moi, chips, etc.

iv. Skills in Fruit Drinks: Juice making such as mango, orange, pineapple, tomato, soya beans, milk, jam making etc.

Uzoka (2010) further enthuses that women who are exposed to these skills are likely to become self-employed by opening up small scale industries where they will be producing and marketing in small quantities. If employed, they also want to work in restaurants, cafeteria, tailoring (garment industries and dress making shops), as nannies in child-care services, food processing and similar business concerns.

What follows from this review is the need to design an appropriate entrepreneurship skills curriculum for women who desire training in such skills. For any adult education program to be effective, it would require exploring a need-oriented approach in discovering what the potential participants would like to learn and how they would want to learn.

\subsection{Research Questions}

The following research questions guided the study.

- What is the demographic characteristics of the respondents participating in the ABE programs?

- What is their perception of the curriculum of the ABE program?

- What entrepreneurial skills do the women adult learners desire to learn?

\section{Methodology}

\subsection{Study Design}

The descriptive survey was adopted for the study.

\subsection{Area of the Study}

The study was carried out in Cross River State of Nigeria. It is located in the Southern Eastern part of Nigeria; and one of the 9 states that make up the Niger Delta Region where crude oil is produced. However, the state is no longer an oil producing state since its oil rich Bakassi region was ceded to Cameroon by the International Court of Justice in 2002. The state is one of the 36 States that make up the federation of Nigeria. It has 18 administrative divisions, generally referred to as Local Government Areas (LGAs). Each L.G.A. has a headquarter where the administrative pharaphenalia are located. Incidentally, the local government headquarters are the main urban centres, while the surrounding villages represent the rural areas or countryside.

Cross River State is chiefly a Civil Service State, with some few cottage, industries and employing only 10 percent of the total population of 2.8million people (Federal Republic of Nigeria, 2006, National Population Census). It is therefore more or less an agrarian society, whose citizens are engaged in food and cash crop production.

\subsection{Population of the Study}

There are a total of 343 adult basic education (ABE) centres in C.R.S. These centers have enrolled a total of 17,278 adult learners as at 2010 (Agency for Adult and Non-formal Education, 2011). 10,864 participants representing $62.9 \%$ are women, while that of men is $6,404(37.1 \%)$. Women adult learners that have enrolled in the $\mathrm{ABE}$ centres form the major population of the study. 


\subsection{Sampling Technique and Sample Size}

Three towns, namely Calabar Municipality (an urban centre), Obudu (a semi urban centre) and Sankwala (a predominantly rural based community) with a total of $10 \mathrm{ABE}$ centres were purposively drawn for study. 240 adult women learners who are enrolled in these centers were all chosen for study.

\subsection{Instrument}

The focus group discussion followed by semi-structured interviews were, the main instrument used in the study. The researcher employed and trained $10 \mathrm{ABE}$ facilitators who assisted him in collecting data from the respondents in their respective centers. In the focus group, subjects were divided into smaller groups to discuss and brainstorm on their perception of current $\mathrm{ABE}$ curriculum and what entrepreneurial skills training they desire to learn that would motivate them to continue attending ABE programs. Semi-structured interviews further helped to probe the issues in detail and to ascertain their demographic characteristics.

Adapting an approach employed by Van der Linder and Rungo (2006), a preliminary content analysis of the results and observations was presented and further elaborated in feedback sessions with respondents and facilitators in the selected centers. These sessions provided opportunity to check the validity of the results and to explore recommendations for program improvement.

\section{Result and Discussion}

The results of the findings are presented with discussions based on the research questions formulated for the study. Frequencies, percentages and bar charts were used to analyze the data.

Research Question 1: What is the demographic characteristics of women learners participating in the ABE program?

Table 1. Demographic profile of adult (women) learners

\begin{tabular}{|c|c|c|c|c|}
\hline $\mathbf{S} / \mathbf{N}$ & & Variables & $\mathbf{F}$ & $\%$ \\
\hline \multirow{3}{*}{1} & \multirow{3}{*}{$\begin{array}{l}\text { Educational } \\
\text { Status: }\end{array}$} & Never went to school & 58 & 24.2 \\
\hline & & Dropped out of school & 169 & 70.4 \\
\hline & & Completed primary school & 13 & 5.4 \\
\hline \multirow{3}{*}{2} & \multirow{3}{*}{ Age: } & Young: $15-39$ & 137 & 57 \\
\hline & & Middle Age: $40-55$ & 82 & 34.2 \\
\hline & & Old Age: 56 and above & 21 & 8.8 \\
\hline \multirow{3}{*}{3} & \multirow{3}{*}{ Marital Status: } & Single & 103 & 42.9 \\
\hline & & Married & 91 & 37.9 \\
\hline & & Separated/Divorced/Widowed & 46 & 19.2 \\
\hline \multirow{4}{*}{4} & \multirow{4}{*}{$\begin{array}{l}\text { *Occupational } \\
\text { Status: }\end{array}$} & Housewife & 111 & 46.3 \\
\hline & & Farming & 134 & 55.8 \\
\hline & & Petty trader/small business & 83 & 34.6 \\
\hline & & Others & 26 & 10.8 \\
\hline
\end{tabular}

(* On occupational status, some respondents responded to more than one item)

Four variables on the demographic characteristics of women were considered crucial to their participation in adult basic classes. (See Table 1). Data on their educational background shows that 24.2 percent of the subjects had never been to school before. Their reasons for participation would mean they want to become lettered and perhaps to learn other skills. The same reason may be adduced for those who attempted school earlier in life but could not complete (70.4\%). They, like the first group must have seen the benefits of being educated, hence returning once more to become lettered and acquire a skill. Those who are already literate $(5.4 \%)$ must be participating in order to learn a skill. In Calabar Municipality, one centre is teaching some vocational skills. 


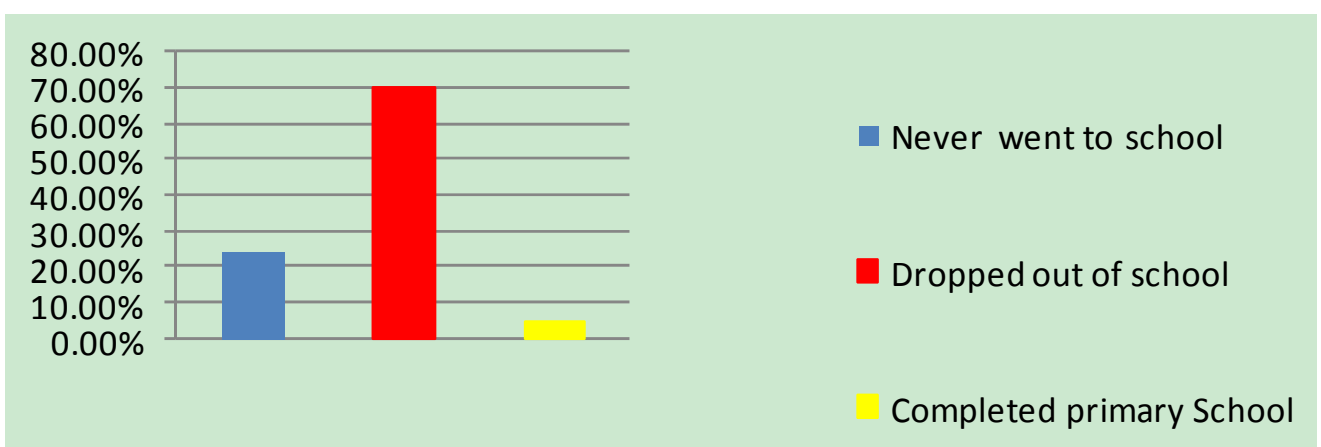

Figure 1a. Bar chart demographic analysis by educational status

The factor of age shows that majority of the participating women are young (57\%). 34.2 percent are in their middle ages. While 8.8 percent ( 21 out of 240 ) are 56 years plus. As depicted here, it would appear that age is a barrier to participation. The reason simply that some of them may consider themselves too old to learn, or have past their productive years, or have become grandmothers.

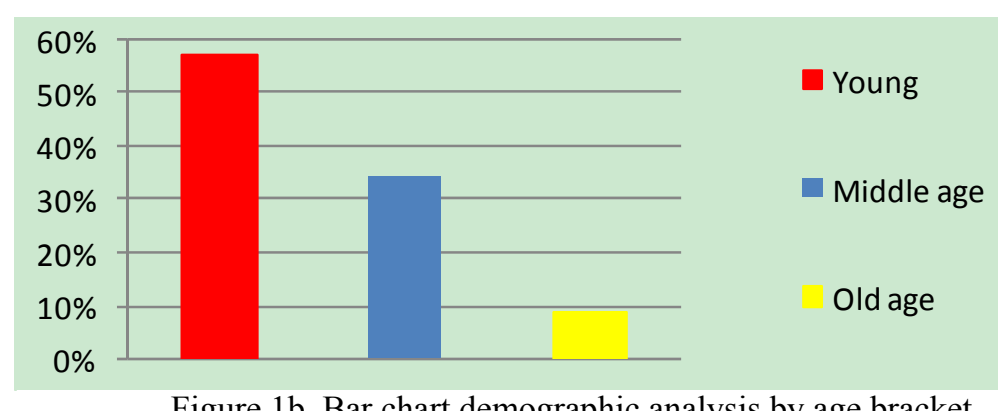

Figure 1b. Bar chart demographic analysis by age bracket

Like the age factor where most participants are young, majority of the women are single or yet to marry. (42.9\%). $37.9 \%$ percent have married. Those who may be separated from their husbands either for economic reasons or misunderstanding, etc, along with those who have divorced and or have lost their spouses are least, with $19.2 \%$ participating. The general observation however is that marital status does not seem to be a barrier as both single and married want to better their lot.

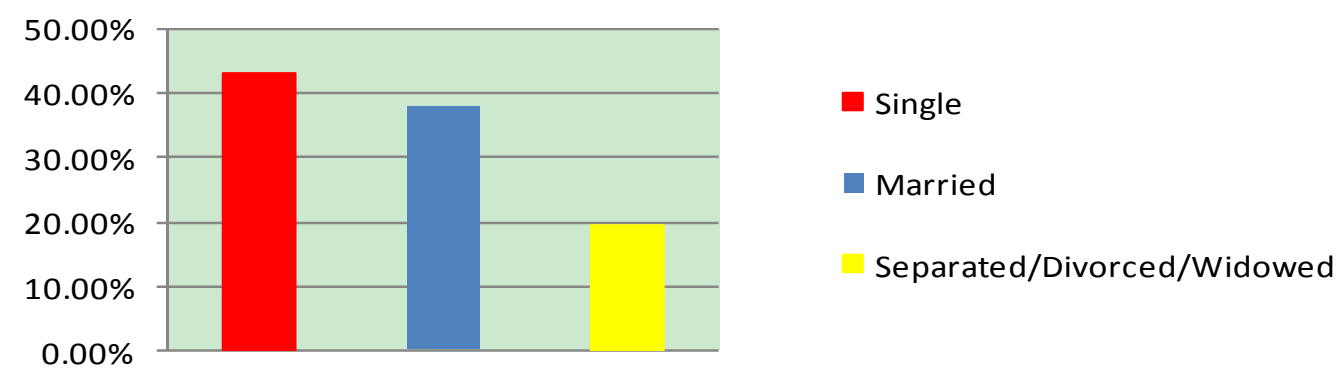

Figure 1c. Bar chart demographic analysis by marital status

Finally, on occupational status, quite a good number of them as expected, are into farming (55.8\%). This is the traditional occupation of our people. Although 46.3 percent claimed they are just housewives; it is however common knowledge that as housewives they do a lot of domestic chores and other petty sales to make ends meet. 34.6 percent are either petty traders or are engaged in one form of small business or the other. The remaining 10.8 percent claimed they are either house helps or simply doing nothing. These ones may be single, young and still staying with their parents. 


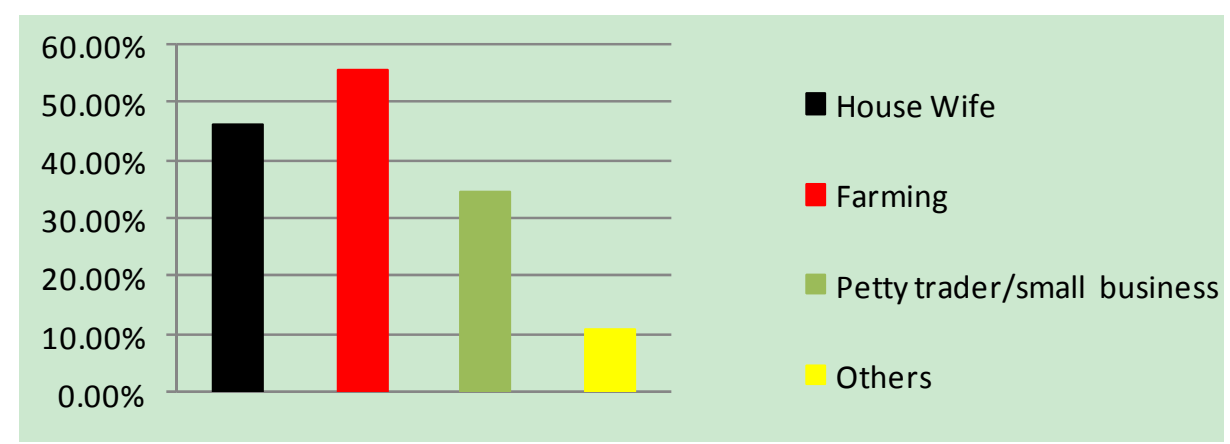

Figure 1d. Bar chart demographic analysis by occupational status

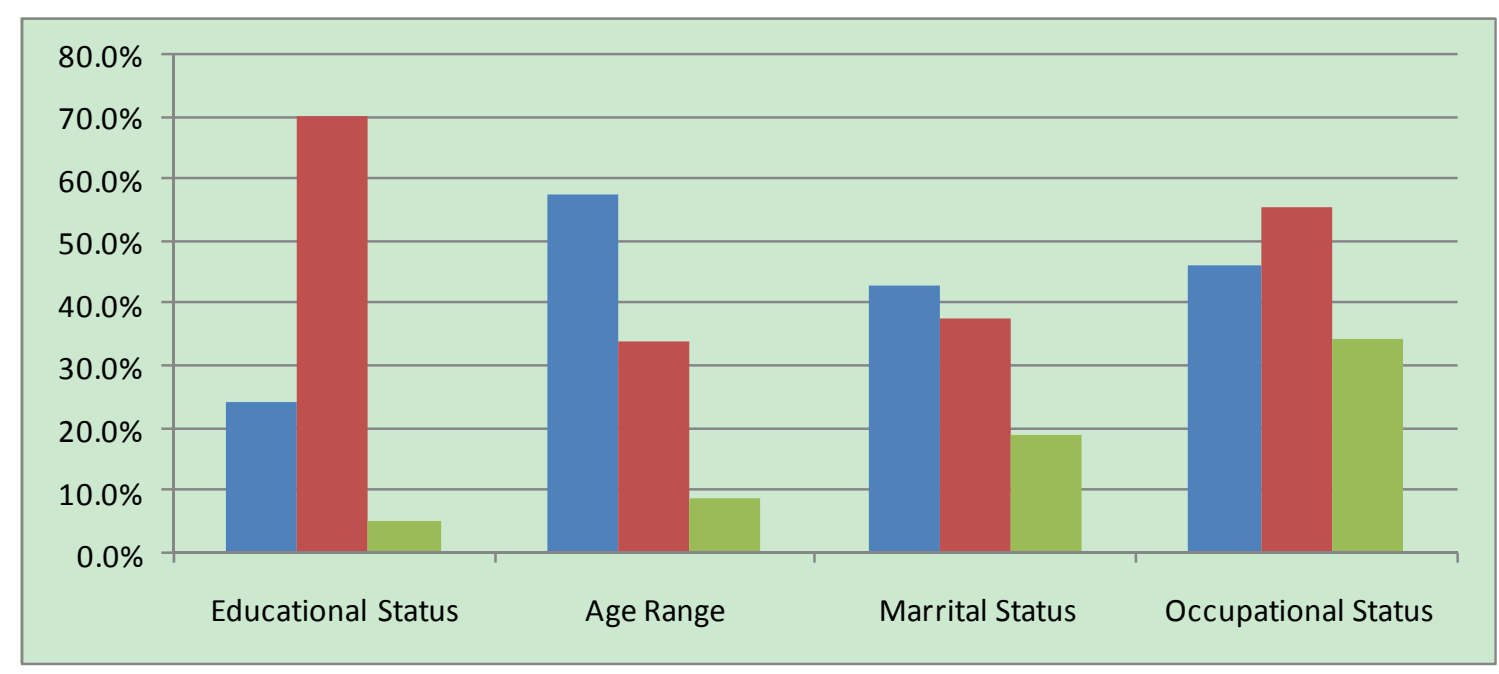

Figure 2. Composite bar chat of respondents' demographic profile

Research Question 2: What is the perception of women on the current ABE programs organized in Cross River State?

Table 2. Perception of participants on the status of ABE program

\begin{tabular}{llll}
\hline $\mathbf{S} / \mathbf{N}$ & \multicolumn{1}{c}{ Items } & \multicolumn{1}{c}{ F } & \multicolumn{1}{c}{$\%$} \\
\hline 1 & Exposes me to social, citizenship, health and political issues. & 240 & 100 \\
2 & Helping me to improve on self and family income & 33 & 13.6 \\
3 & Acquiring just literacy skills will not solve my economic problems & 211 & 88 \\
4 & Wish it could help me learn a vocation/job so that I can improve my earning status & 207 & 86.3 \\
5 & Just attending to broaden my knowledge & 28 & 11.7 \\
\hline
\end{tabular}

N/B: The information in Table 2 is provided in Pie Chart analyses in figures 2.1, 2.2 \& 3 and 2.4 and 5.

Table 2 highlights what the women perceive they are gaining/or not gaining from the ABE classes. As the responses suggest many of them state more than one reason. From the Table 2, there is a consensus among the women that the ABE program is helping them to acquire citizenship, social, health and political skills (See Item I, $100 \%$ ). This is achieving the National Objectives of enlightening people (and particularly the illiterates) on the issues that improve ones personal and social development. Apart from this, only 13.6 percent affirm that the $\mathrm{ABE}$ program is improving their family income. The consequences of the program not improving the earning status of the remaining $86.4 \%$ of women are obvious. Without improved income, the gains of enhanced social, 
citizenship, health and political participation may be eroded. Money is needed to empower these women, care for their family, pay for good health, provide good nutritious food, etc. Thus, literacy is a means to an end and not an end in itself. That is why only 88 percent of the subjects are saying that acquiring basic literacy skills per se will not solve their economic problem. Hence, $86.3 \%$ of the participants want to learn at least one entrepreneurship skill along side the literacy skills which is likely to improve their earning status. Otherwise, the problem of poverty will not be overcome.

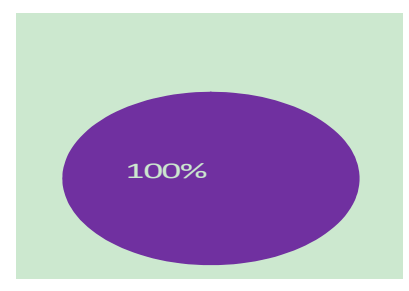

Figure 2.1. Pie chart analysis of subject responses to item 1

(RQ 2.1: On exposure to social, citizenship, health and political issues).

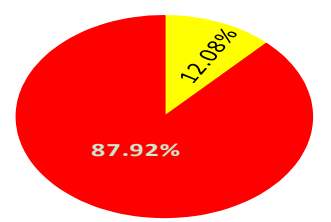

Figure 2.2. Pie chart analysis of subjects responses to items $2 \& 3$

RQ $2.2 \& 3$ : On improvement on self and family income

Literacy skill acquisition will not solve economic problem

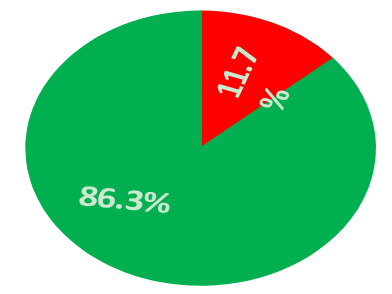

Figure 2.3. Pie chart analysis of subjects responses to items $4 \& 5$

RQ 2.4 \& 5: Wish on vocation

Job for improvement on earnings and just to broaden knowledge

Research Question 3: What entrepreneurship program do women desire to learn?

Table 3. Entrepreneurship skills preferred by women

\begin{tabular}{|c|c|c|c|}
\hline $\mathbf{S} / \mathbf{N}$ & Entrepreneurship Training & $\mathbf{F}$ & $\%$ \\
\hline \multirow[t]{2}{*}{1} & Agricultural Training: & & \\
\hline & $\begin{array}{l}\text { Acquire skills in gardening, crop production, processing and marketing, animal } \\
\text { husbandry, fishing, snailing, bee keeping, agricultural credit, record keeping and } \\
\text { accounting, etc. }\end{array}$ & 79 & 33 \\
\hline \multirow[t]{2}{*}{2} & Electrical/Electronic, Mechanical, Building Construction: & & \\
\hline & $\begin{array}{l}\text { Acquire skills in electrical fittings and repairs, electronic repairs, motor cycle/car } \\
\text { repairs, wood work and furniture, carpentry, painting, masonry and building, etc. }\end{array}$ & 21 & 8.8 \\
\hline \multirow[t]{2}{*}{3} & Home Economics (Home Management): & 136 & 56.7 \\
\hline & Child-care, food and nutrition, fruit processing, bakery, cosmetology, hair dressing, & & \\
\hline
\end{tabular}


soap making, laundry, etc.

4 Home Economics (Clothing and Textiles):

Tailoring and dress-making, knitting and weaving, embroidery, clothes repairs, etc.

5 Computer/Secretarial Training:

Typing, shorthand, word and data processing, salesmanship, book keeping, store

keeping, accounts keeping, etc.

N/B: Many respondents indicated more than one entrepreneurial skills, implying they need training in more than one. (See also Pie charts analyses as shown in figures $3 \mathrm{a}$ and $3 \mathrm{~b}$ ).

The pattern of response as shown in Table 3 above shows that the participants are more or less incline to acquire entrepreneurial skills in such culturally determined feminine subjects as in Home Economics.

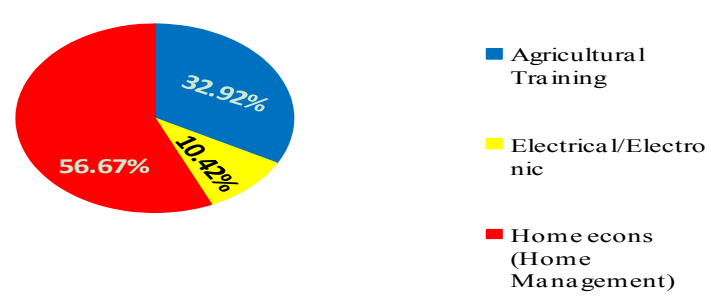

Figure 3a. Pie chart analysis on preferred entrepreneurship skills (A)

(RQ 3.2 a, b \& c: Prefered entrepreneurship skills, (A))

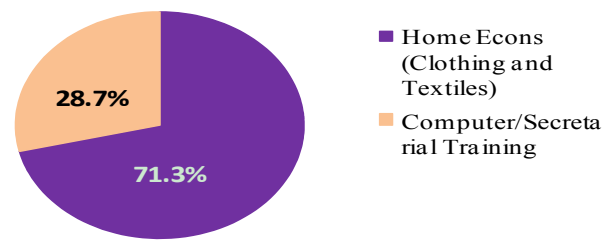

Figure 3b. Pie chart analysis of preferred entrepreneurship skills (B)

(RQ 3.2 d \& e: Prefered entrepreneurship skills (B))

As indicated in items 3 and $4,56.7 \%$ and $50.4 \%$ of the women desire to acquire skills in either Home Management or Clothing and Textiles. This could be a familiar terrain and they may acquire the skills easily and set up their own businesses. It is likely that some of them are already hairdressers, tailors or involved in some of these jobs.

However, acquisition of skills in agricultural production which our women are very familiar with came a distant third, with 79 (or 33\%) of the respondents desiring training in that sector. Working under the scorching sun and the uncertainty in crop yields, etc might have made a lot of people acquire a disdain for agriculture, more so, the women under consideration. It is possible that the respondents who chose this sector reside in the rural areas.

Computer and secretarial training came fourth. $28.3 \%$ of the women will prefer to acquire skills in either word or data processing, shorthand and typewriting, etc. It is possible that the respondents who desire training in these skills are young and are found mostly in the urban sector where computer business is thriving. Finally, the most interesting finding relate to the almost non-acceptance by the respondents in developing interest in studying entrepreneurial skills in electrical/electronic, mechanical, and building construction sectors. Only 21 or 8.8 percent of the women chose either of these skills. Traditionally, these skills have been exclusively performed by men (Bellew and King, 1993; Schultz, 1993). That $8.8 \%$ of the women desire training in any of these skills is surprising. It is like delving into the unknown, or "what a man can do, a woman can do better".

\section{Conclusion}


This study has shown that majority of the women who are participating in the adult basic education program in Cross River State are not satisfied with the learning experiences that are being provided. Exposing them to acquire mainly literacy, numeracy, social and citizenship skills at the expense of entrepreneurial skills has not improved their status not that of the family. The implication is that the current policy in which the curriculum of the $\mathrm{ABE}$ program is planned at the federal level should be decentralized in order to cater for the needs of learners at the local level. There is therefore a need to make the curriculum relevant to their needs and interests. The entrepreneurial skills desired by women should be properly developed and integrated into the literacy programs to motivate them to attend classes regularly. Training in acquiring entrepreneurship skills should precede literacy classes.

The curriculum can be greatly improved upon by involving the learners in the determination of their training needs. Individually and in groups, they can be guided to reveal what entrepreneurship skills they are interested in learning. At the program level and community-wide setting, facilitators, coordinators, community leaders, etc can also assist in improving the ABE program by identifying the entrepreneurship skills that can benefit women learners most.

The Federal, State and Local Governments should partner with the private sector and non-governmental organizations to make the entrepreneurship training programs workable. For instance, the three tiers of government should identify with established entrepreneurs in the communities like in bakery, fashion designing, catering, cassava/garri processing, etc who will provide professional training. While government would provide facilitators who should teach communication, social and political skills.

Finally, non-governmental and community-based organizations should, as it were, be encouraged through governmental support establish and run centres to help these women acquire the desired skills. When they are exposed to these skills and with some credit facilities they would know what to do with their newly acquired entrepreneurial knowledge and skills.

\section{References}

Adidu, F. A., \& Olannye, A. P. (2006). Basic small business entrepreneurship: A modern approach. Agbor, Nigeria: Royal Pace Publications.

Agency for Adult and Non-Formal Education, Cross River State. (2011). Statistics of literacy rates for the $1^{\text {st }}$ quarter, 2010. Calabar, Nigeria: Agency for Adult and Non-formal Education.

Agetue, F. N., \& Nnamdi, A. E. (2011). Entrepreneurship training: A tool for job creation in Nigeria. Journal of Teacher Perspective, 5(3), 475-482.

Akinpelu, J. A. (2002). Philosophy and adult education. Ibadan, Nigeria: Stirling-Horden Publishers.

Asia South Pacific Bureau of Adult Education. (2006). Resourcing for quality: Adult literacy learning. Adult Education and Development, 66, 45-64.

Bellew, R. T., \& King, E. M. (1993). Educating women: Lessons from experience. In E. M. King, \& M. A. Hill, (Eds.), Women's education in developing countries. London, England: The John Hopkins University Press.

Federal Ministry of Education. (1999). Universal basic education (UBE): Implementation guidelines. Abuja, Nigeria: Federal Republic of Nigeria.

Federal Ministry of Education. (2000). Comprehensive Education Analysis Project/Secondary Data Report, Abuja. FGN/UNICEF/UNESCO/UNDP.

Federal Ministry of Education. (2004). National blue print for adult and non-formal education. Abuja, Nigeria: National Commission for Mass Literacy, Adult and Non-formal Education.

Federal Ministry of Education. (2007). Nigeria education sector diagnosis. UNESCO.

Ingwu, E. U., Ifere, A. B. E., \& Abanbeshie, J. (2012). Adult basic education as a strategy for eradicating illiteracy and empowering adults for sustainable livelihoods. Journal of Resourcefulness and Distinction, 2(1), 154-164.

Lauglo, J. (2002). A case for renewed engagement in adult basic education in Africa. Adult Education and Development, 58, 67-82.

Lees, R. (1975). Curriculum development and the community approach. In R. Lees, \& G. Smith (Eds.), Actionresearch in community development (pp. 123 - 127). London, England: Routledge and Kegan Paul.

Lowe, J. (1975). The Education of adults: A world's perspective. Paris: The UNESCO Press. 
Marstaller, A. (2012). First things first: Female literacy as the key to women's advancement. Retrieved October 7, 2013, from http://eputs.utah.edu/index.php/HJP/article/viewfile/662/505

Nwodoh, E. O. (2011). Entrepreneurship and functional vocational education as a means of achieving the national objectives of vision 20:20:20 in Nigeria. Approaches in International Journal of Research Development, 4(1), 296-303.

Okeem, E. O. (1998). Towards assessing the impact of literacy education in the role of the Nigerian woman in development. In M. Omolewa, E. E. Osuji, \& A. Oduaran (Eds.), Retrospect and renewal: The state of adult education research in Africa (pp. 251 - 256). Dakar, Senegal: UNESCO-BREDA.

Onwubiko, C. A. C. (2012). Empowerment of women towards national development. Journal of Resourcefulness and Distinction, 2(1), 68-78.

Oxenham, J. (2004). ABET vs poverty: What have we learned? Adult Education and Development, 63, 83-102.

Oxenham, J. et al. (2002). Skills and literacy for better livelihoods: A review of approaches and experiences. Adult Education and Development, 58, 8-44.

Schultz, P. T. (1989). Benefits of educating women. World Background Paper Series, Education and Employment Division, Population and Human Resources Department, Washington, D. C.

Schultz, P. T. (1993). Returns to women's education. In E. M. Kings, \& M. A. Hill (Eds.), Women education in developing countries. London, England: The John Hopkins University Press.

Suso, E. (2006). An analysis of the place of literacy in poverty reduction strategy papers. Adult Education and Development, 66, 239-250.

Thompson, E. J. D. (2002). Putting bread on the table: The effects of literacy and livelihood. Adult Education and Development, 59, 97-116.

Todaro, M. P., \& Smith, S. C. (2003). Economic development (8th ed.). Delhi, India: Pearson Education.

Udo-Aka, U. (2000). The trainer and self employment: A case of social responsibility. Nigerian Management Review, 12(1\&2), 855-861.

UNESCO (n.d.). Handbook for non-formal education facilitators (module two: Identification of learning needs). Retrieved October 7, 2013, from http://www.2.unescobkk.org/elib/publications/non-formal/N2.pdf

Uzoka, F. A. (2010). Role of home economics education in poverty alleviation in Nigeria. In E. C. Iloputafe, B. U. Maduewesi, \& R. O. Igbo. (Eds.), Issues and challenges in Nigerian education in the $21^{\text {st }}$ century (pp. 199-214). Onitsha, Nigeria: West and Solomon Publishing Company,

Van der Linden, J., \& Rungo, R. (2006). Being literate means being somebody: Perceptions of participants of literacy programmes in Mozambique. Adult Education and Development, 66, 283-296.

\section{Copyrights}

Copyright for this article is retained by the author(s), with first publication rights granted to the journal.

This is an open-access article distributed under the terms and conditions of the Creative Commons Attribution license (http://creativecommons.org/licenses/by/3.0/). 